\title{
Sprawozdanie z XXX Letniej Szkoły Młodych Pedagogów Katowice - Wisła, 12-16 września 2016
}

\begin{abstract}
STRESZCZENIE
Zaprezentowany niżej tekst stanowi swoistą próbę sprawozdania $\mathrm{z}$ najważniejszych i priorytetowych wydarzeń, mających miejsce podczas trwania wyjątkowej, bo jubileuszowej - XXX Letniej Szkoły Młodych Pedagogów pod naukowym kierownictwem prof. Marii Dudzikowej oraz współorganizowanej przez KNP PAN i Uniwersytet Śląski z Wydziałem Pedagogiki i Psychologii w funkcji gospodarza. Rozważania tegorocznej Szkoły oscylowały wokół tematu: „Pułapki badań nad edukacją”. Celem spotkania Młodych Pedagogów była wymiana poglądów oraz doświadczeń, dotyczących metodologicznych niejasności i zawiłości oraz stworzenie dogodnej, interdyscyplinarnej przestrzeni o charakterze inspirującym, wyjaśniającym, ukierunkowującym i budującym.

SŁowA KluCzowe: Letnia Szkoła Młodych Pedagogów, pułapki badań.
\end{abstract}

Na jednej ze stron książki autorstwa Theresy Revay znajduje się fragment, który w sposób szczególny odnieść można do idei organizowania Letnich Szkół Młodych Pedagogów, podkreślając ich znaczenie i wyjątkowość:

„Spotkania wytyczają drogę ludzkiego losu, niezależnie od tego, czy trwają kilka godzin, kilka dni czy całe życie".

Letnia Szkoła Młodych Pedagogów jest tym spotkaniem, dzięki któremu wyodrębniane i wytyczane zostają nowe ścieżki, inicjujące i generujące innowacyjne pomysły oraz niecodzienne przedsięwzięcia. Tegoroczna Szkoła, po raz 23. objęta naukowym kierownictwem przez prof. Marię Dudzikową, przybrała charakter wyjątkowego i niepowtarzalnego spotkania oraz pożądanego zdarzenia intelektualno-refleksyjnego, którego tematem przewodnim stały się PUŁAPKI BADAŃ NAD EDUKACJĄ. W dniach 12-16 września 2016 roku nastąpiło w Katowicach i Wiśle niezwykle konstruktywne zderzenie rozmaitych, niejednoznacznych i nierzadko dychotomicznych przemyśleń oraz rozległych doświadczeń. Liczba uczestników pozytywnie zaskoczyła samych organizatorów, którzy żywią nadzieję, że dla wielu przybyłych na letnioszkolne obrady 
spotkanie na Śląsku pozostanie w pamięci na długo ze względu na szczególną atmosferę oraz bogate ukierunkowujące dyskusje z samymi Mistrzami, więc licznym gronem zaproszonych profesorów, zaangażowanych w pracę nad swoimi podopiecznymi i... samym sobą.

XXX Letnia Szkoła Młodych Pedagogów, pod patronatem Polskiej Akademii Nauk, współorganizowana przez Komitet Nauk Pedagogicznych i Uniwersytet Śląski w Katowicach, była przedsięwzięciem, którego gospodarzem został Wydział Pedagogiki i Psychologii Uniwersytetu Śląskiego w Katowicach. Jubileuszowe wydarzenia domagały się szczególnej organizacji. Jubileusz - z definicji - stanowi uroczystość wyczekiwaną i obchodzoną nieczęsto, w związku z czym XXX Letnia Szkoła Młodych Pedagogów musiała zostać zaplanowana, zorganizowana i przeprowadzona w taki sposób, by zapamiętana została jako wydarzenie wyjątkowe (nad czym czuwał ośmioosobowy Komitet Organizacyjny, na czele z dr. Łukaszem Michalskim jako Sekretarzem Naukowym XXX LSMP i mgr Katarzyną Maliszewską). Pojedyncze, dotychczasowe logo LSMP zostało zmienione na potrójne, wskazujące na jubileuszową liczbę, oraz podkreślające ideę organizacji szkół, sprzyjających współdziałaniu, współuczestnictwu oraz wzajemnej interakcji.

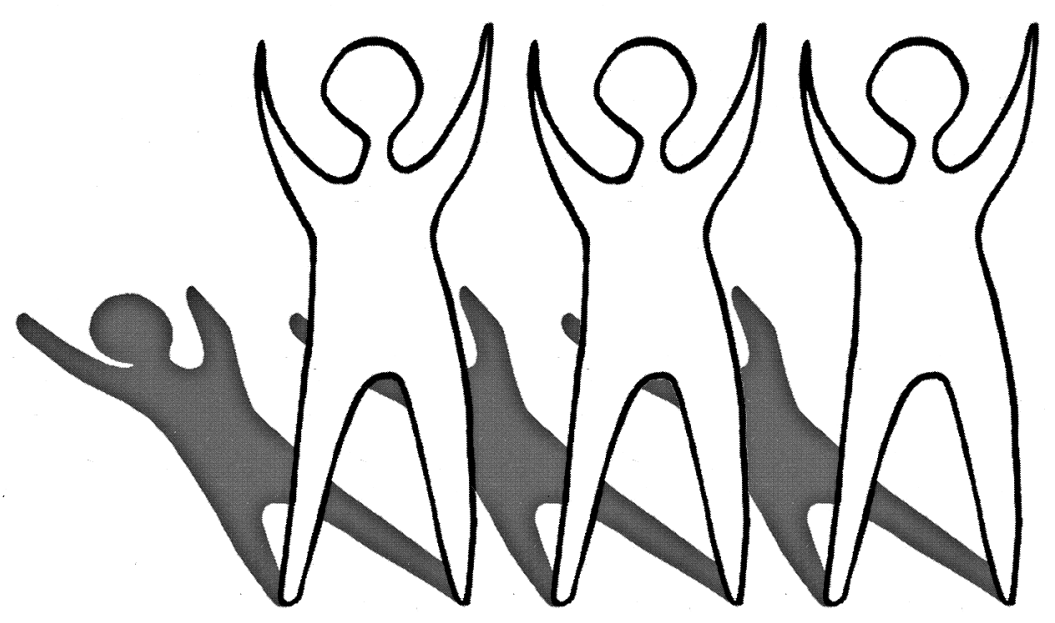

Specyfika Letnich Szkół Młodych Pedagogów sprzyja idei integracji różnorodnych środowisk akademickich, wymianie i rozpowszechnianiu znaczących poglądów i wyników badań oraz samodzielnemu podejmowaniu dialogu. Po raz trzydziesty cele wyodrębnione podczas planowania XXX LSMP były skutecznie realizowane, umożliwiając Młodym Pedagogom prezentację własnych przemyśleń, które tematycznie skoncentrowane zostały wokół 
problematyki metodologicznej, oraz pozwalając na uczestniczenie w indywidualnych i zbiorowych spotkaniach o charakterze stricte refleksyjnym, także intrygującym i bezsprzecznie inspirującym.

Uroczysta ceremonia otwarcia XXX LSMP odbyła się 12 września 2016 roku w niezwykłym budynku Międzynarodowego Centrum Kongresowego w Katowicach, przynależącego do Strefy Kultury, czyli nowo powstałej części Katowic, która została zagospodarowana z myślą o działalności kulturalnej regionu. Podczas ceremonii otwarcia Letniej Szkoły Młodych Pedagogów, wszystkich zebranych przywitał Dziekan Wydziału Pedagogiki i Psychologii UŚ - prof. Stanisław Juszczyk oraz JM Rektor Uniwersytetu Śląskiego - prof. Andrzej Kowalczyk. W pierwszej części ceremonii inaugurującej wystąpili: Przewodniczący KNP PAN - prof. Bogusław Śliwerski, oraz w imieniu Prezydenta Miasta dr. Marcina Krupy, Wiceprezydent Waldemar Bojarun. Po części wstępnej wystąpiła również prof. Maria Dudzikowa, podkreślając rolę integracji, współpracy naukowej i pedagogicznej oraz nakreślając problematykę XXX LSMP. Następnie dr hab. Ewa Bochno, w oparciu o materiał wizualny, dokonała ważnej retrospekcji i ukazała zgromadzonym gościom oraz uczestnikom tegorocznej szkoły 29 minionych odsłon LSMP oraz wprowadziła w jubileuszową książkę NAUKOWA wSPÓLNOTA UCZĄCYCH się. XXX-lecie Letniej Szkoły MŁodych Pedagogów przy KNP PAN (red. E. Bochno, A. Korzeniecka-Bondar), przygotowaną specjalnie na czas tegorocznej Szkoły. Zaprezentowany został także przez dr Martę Krasuską-Betiuk kolejny tom Zeszytów Naukowych Forum MŁodych Pedagogów (pt. O POSZUKIWANIU, POZNAWANIU I TWORZENIU SAMEgo SIEBIE) jako owoc obrad XXIX LSMP.

12 września 2016 roku w Centrum Kongresowym dokonano również wręczenia jubileuszowych nagród przyjaciołom i zasłużonym dla LSMP. Przede wszystkim statuetkę upamiętniającą trzydziestą odsłonę Szkoły otrzymała prof. Maria Dudzikowa w podziękowaniu za wieloletnie kierowanie wzrastaniem idei spotkań młodych badaczy z Mistrzami. Wręczono także jubileuszowe medale za szczególny, wieloletni udział w historii Letnich Szkół i mistrzowskie zaangażowanie; otrzymali je: prof. Bogusław Śliwerski, prof. Maria Czerepaniak-Walczak, prof. Zenon Gajdzica. Jubileuszowy medal został także przekazany rodzinie zmarłej w tym roku prof. Elżbiety Tarkowskiej, przez lata wspierającej Letnie Szkoły. Wśród wyróżnionych osób znaleźli się także: prof. Tadeusz Lewowicki, prof. Zbigniew Kwieciński, prof. Lech Witkowski, prof. Wiesława Limont, prof. Eugenia Potulicka, prof. Jerzy Nikitorowicz, prof. Aleksander Nalaskowski, prof. Henryka Kwiatkowska i prof. Stefan Kwiatkowski. Wręczono także medale pamiątkowe dla przyjaciół wspie- 
rających ideę Letnich Szkół StrzaŁy w 30 (dr hab. Ewa Bochno, dr hab. Małgorzata Makiewicz, dr hab. Przemysław Grzybowski, dr Alicja Korzeniecka-Bondar) oraz Strza£y w 10 (dr hab. Piotr Mikiewicz, dr hab. Alina Wróbel, dr hab. Justyna Dobrołowicz, dr hab. Monika Wiśniewka-Kin, dr Marta Krasuska-Betiuk, mgr Aleksander Cywiński, dr Zofia Remiszewska, dr Jolanta Sajdera, dr Bożena Tołwińska, dr Katarzyna Szorc, dr Katarzyna Braun, dr Dorota Bis, ks. dr Marek Jeziorański, dr Edyta Nieduziak). Ważnym punktem ceremonii otwierającej pięciodniowe spotkanie Młodych Pedagogów było również uroczyste przekazanie przez Dziekana Wydziału Pedagogiki i Psychologii UŚ, prof. Stanisława Juszczyka, insygniów LSMP na ręce Dziekana Wydziału Nauk Pedagogicznych - ks. prof. Jana Niewęgłowskiego, który został jednocześnie mianowany gospodarzem XXXI Letniej Szkoły Młodych Pedagogów. Zwieńczeniem pierwszej części uroczystości, jednoznacznie sygnalizującym rozpoczęcie niezwykłej, jubileuszowej XXX LSMP, był wyczekiwany wykład prof. dr. hab. Tadeusza Sławka, zatytułowany: NiE BęDzIE ZYSKU, NIE BęDZIE RADOŚCI. EdUKACJA, JEDNOSTKA, WSPÓLNOTA, oraz występ jazzowo-soulowego zespołu muzycznego Coffee Experiment, który w sposób niespotykany przeniósł wszystkich zebranych w świat muzycznych doznań. Po zakończeniu części inauguracyjnej w Międzynarodowym Centrum Kongresowym w Katowicach, wszyscy uczestnicy LSMP oraz zaproszeni Goście przenieśli się do budynku znajdującego się przy ulicy Grażyńskiego 53 .

Gmach przy ulicy Grażyńskiego 53 w Katowicach to Wydział Pedagogiki i Psychologii Uniwersytetu Śląskiego, który wyodrębnił się jako samodzielna jednostka w roku 1976 z Instytutu Pedagogiki i Psychologii, utworzonego 3 lata wcześniej na Wydziale Nauk Społecznych. To w tym właśnie miejscu wszyscy uczestnicy XXX Letniej Szkoły Młodych Pedagogów zostali zaproszeni na obiad, po którym Dziekan Wydziału, prof. Stanisław Juszczyk, oraz prof. Ewa Syrek (Kierownik Pedagogiki Społecznej) i dr hab. Ewa Szadzińska (Kierownik Instytutu Pedagogiki) przedstawili poszczególne jednostki Wydziału. Następnie prof. Ewa Wysocka zaprezentowała wykład Dziś PRAWDZIWEJ MŁODZIEŻY JUŻ NIE MA? BUNT AKSJOLOGICZNY CZY EGOCENTRYCZNY W PROCESIE „STAWANIA SIĘ” W PONOWOCZESNYM ŚWIECIE.

Uroczystości na Wydziale Gospodarzy Jubileuszowej Szkoły domknął koncert orkiestry górniczej, po którym uczestnicy LSMP wyruszyli na krótkie zwiedzanie Katowic. Wyprawa na Nikiszowiec, czyli zwiedzanie efektownej dzielnicy, będącej pozostałością po osiedlu robotniczo-górniczym, zakończyła wydarzenia mające miejsce w stolicy Górnego Śląska - uczestnicy wyruszyli do Wisły, gdzie miały odbyć się zasadnicze obrady LSMP. Po dotar- 
ciu do Hotelu Pod Jedlami w Wiśle, rozpakowaniu się i zjedzeniu uroczystej kolacji, uczestnicy Letniej Szkoły Młodych Pedagogów spotkali się z prof. dr hab. Marią Dudzikową, która raz jeszcze pokreśliła konieczność wzajemnej akceptacji, zrozumienia i umiejętnego prowadzenia dialogu, a także współdziałania i współdzielenia się - również (a może przede wszystkim?) własnymi zastrzeżeniami, wątpliwościami, poczuciem niejednoznaczności i destabilizacji metodologicznej w swoim warsztacie badawczym. Wieczór 12 września 2016 roku, po licznych konsultacjach, naradach, rozmowach, zakończył się bardzo późno i był zwiastunem zintensyfikowanej pracy każdego kolejnego dnia trwania XXX Letniej Szkoły Młodych Pedagogów.

Od wtorku 13 września do piątku 16 września wszyscy uczestnicy brali udział w różnorodnych rozmowach, indywidualnych konsultacjach, wspólnych dyskusjach, seminariach tematycznych, wystąpieniach Młodych oraz wykładach Mistrzów, połączonych z dyskusją. W trakcie trwania jubileuszowej XXX Letniej Szkoły Młodych Pedagogów:

1) codziennie odbywała się Giełda Próżności, podczas której młodzi badacze mogli podzielić się z innymi własnymi przeżyciami, doświadczeniami, emocjami i wiedzą;

2) zorganizowano i zrealizowano 16 wykładów Mistrzów, połączonych $\mathrm{z}$ dyskusją, w następującej kolejności:

- prof. Jacek Piekarski: Wiarygodność PRAKTYKi BADAWCZej W WARUNKACH KORPORATYZACJI NAUKI,

- prof. Jarosław Gara: FenOMEN NIEREdUKOWALNOŚCI TEORII I PRAKTYKI PEDAGOGICZNEJ,

- prof. Danuta Urbaniak-Zając: JAK BADAĆ TO, o CZYM NIE WIEMY? O PROBLEMACH BADAŃ JAKOŚCIOWYCH,

- prof. Andrzej Góralski: Elementy teoril statystyki kWALitatywNEJ ORAZ PRZYKŁADY ZASTOSOWAŃ W HUMANISTYCE,

- dr hab. Piotr Mikiewicz: Dlaczego teoria ma znaczenie - z PerSPEKTYWY FANATYKA KONSEKWENTNEGO STOSOWANIA TEORII EMPIRYCZNYCH,

- prof. Maria Czerepaniak-Walczak: Źródea I KonseKwencje UproszCZEŃ W BADANIACH W DZIAŁANIU,

- prof. Krzysztof Rubacha: ANAliza I INTERPRETACja JAKo ETAPY PROCESU BADAWCZEGO W NAUKACH SPO€ECZNYCH,

- dr hab. Monika Wiśniewska-Kin: PuŁaPKi w Badaniach DYskursu DZIECIĘCEGO I JAK JE OMIJAĆ,

- dr hab. Alina Wróbel: Kategoria intencjonalności Jako PRZedMIOT ANALIZY W MOICH TEORETYCZNYCH ZMAGANIACH, 
- prof. Zenon Gajdzica: Pulapki Metodologiczne w badaniach śWiaTA OSÓB Z NIEPEŁNOSPRAWNOŚCIĄ,

- prof. Wiesława Limont: PUŁaPKi W BAdANIACH EKSPERYMentalNyCH

- dr hab. Małgorzata Makiewicz: PuŁapKi w badaniach eKSPerymenTALNYCH - Z DOŚWIADCZEŃ WŁASNYCH I CUDZYCH,

- prof. Bogusław Śliwerski: BŁęDY METOdologiCZne W NABYWANIU NAUKOWEGO HABITUSU,

- dr hab. Ewa Bochno: Niektóre puŁapki w AWANsowych PUblikaCJACH PEDAGOGów,

- dr hab. Justyna Dobrołowicz: PUŁapki w Analizach Dyskursu PraSOWEGO. Z DOŚWIADCZEŃ WŁASNYCH I CUDZYCH,

- dr hab. Przemysław Grzybowski: PuŁapka śmieszności czy sposób Na PrZetrwanie? Poczucie humoru jako element postawy NaUKOWCA I NAUCZYCIELA;

3) odbywały się indywidualne konsultacje z Mistrzami oraz tradycyjne nieobowiązkowe poranne spotkania z prof. Marią Dudzikową;

4) przeprowadzone zostały rozmaite warsztaty, dotyczące między innymi sfery artystycznej (Fundacja W KAŻDYM WIEKU) czy jogi (dr Ewa Gawlik) i relaksacji (dr Edyta Nieduziak) oraz zwiększania widzialności artykułów w internecie (dr hab. Przemysław Grzybowski);

5) zorganizowano i zrealizowano seminaria metodologiczne (prof. Stanisław Juszczyk, ks. prof. Jan Niewęgłowski);

6) zostało zorganizowane Święto Książki, podczas którego uroczyście rozdane zostały zestawy publikacji dla przedstawicieli obecnych na LSMP jednostek badawczych i podkreślona została rola, jaką zapisane słowa odgrywają w naszym życiu, inicjując i katalizując chęć samorozwoju;

7) zorganizowana została wycieczka po Wiśle, połączona ze spotkaniem $\mathrm{z}$ Mistrzem.

Pięć intensywnych oraz pełnych wrażeń i rozmaitych stanów emocjonalnych dni XXX Letniej Szkoły Młodych Pedagogów, z których cztery spędzone zostały w wiślańskim hotelu, były czasem niezwykle intensywnej pracy, poznawania siebie i swoich starych-nowych znajomych, odkrywania nowych pułapek metodologicznych, rozmów, dyskusji oraz identyfikowania i definiowania wielokierunkowych i niejednorodnych wniosków. Dnia 16 września 2016 roku w jednej z sal Hotelu pod Jedlami odbyła się uroczysta kolacja wieńcząca i podsumowująca Jubileuszowe wydanie Letniej Szkoły Młodych Pedagogów, podczas której odbył się tradycyjny kabaret, zorganizowany przez energicznych i żywiołowych uczestników, wręczone zostały nagrody dla osób mających, zdaniem audytorium, najlepsze wystąpienia oraz zło- 
żone zostały podziękowania Komitetowi Organizacyjnemu oraz prof. dr hab. Marii Dudzikowej. Nad częścią artystyczną czuwali mgr Aleksander Cywiński oraz mgr Iwona Murawska, którzy przygotowali i zmobilizowali uczestników LSMP do aktywności w kabaretowym przedsięwzięciu o enigmatycznej nazwie MAGICZNY WIECZÓR, CZYLI O RZECZACH ISTOTNIE WAŻNYCH I POZORNIE WAŻNIEJSZYCH. DESSERTACIONE IN SOLO ET UNA VOCE PEDAGOGENIS.

Nagrodami Audytorium za najlepsze wystąpienie uhonorowani zostali mgr Konrad Pasikowski (w kategorii magister) oraz dr Magdalena Bełza (w kategorii doktor). Nagrodą Twórczy Szum i Twórczy szumek dla osób, które inspirująco zachęcały do dyskusji, zostali odznaczeni kolejno dr Sławomir Pasikowski oraz dr Jolanta Sajdera. W trakcie uroczystej kolacji dokonało się także przekazanie „kociałki” Sekretarz przyszłorocznej Szkoły, dr Kindze Krawieckiej. Po piątkowej kolacji, pożegnalno-jublileuszowym torcie oraz wykupieniu dyplomów uczestnictwa przez osoby reprezentujące rozmaite ośrodki naukowe, wszyscy Młodzi Pedagodzy, Mistrzowie i Goście rozeszli się do pokojów, z których wymeldowali się 17 września 2016 roku. Sobotni poranek stał się bowiem czasem powrotu, inicjującym konieczny okres rozmyślań nad pięciodniowymi wydarzeniami, sytuacjami i spotkaniami, mającymi miejsce podczas XXX Letniej Szkoły Młodych Pedagogów.

Sprawozdanie z XXX Letniej Szkoły Młodych Pedagogów wymaga odpowiedniego zakończenia, dlatego też pozwalam sobie na (dość niekonwencjonalne, aczkolwiek świadome) odwołanie do jednej z części książki autorstwa Tove Jansson, która jest twórczynią niezapomnianego cyklu opowiadań i komiksów o antropomorficznych, sympatycznych stworach - Muminkach. W jednej z części cyklu Opowiadania z Doliny Muminków ukazana została przez fińską pisarkę pewna historia, dotycząca Włóczykija (część: WioSENNA PIOSENKA), który postanowiwszy rozpocząć wędrówkę, próbuje urzeczywistnić układającą mu się w głowie piosenkę. W chwili odpoczynku stara się ją odwzorować, grając na harmonijce, ale przeszkadza mu w tym niewielkich rozmiarów stworzonko, wyznające, że jest istotą całkowicie bezimienną, ale znającą i podziwiającą go. Włóczykij zniecierpliwiony przedłużającym się nieoczekiwanym spotkaniem, próbuje zakończyć niezaplanowaną rozmowę, nadając stworzonku imię Ti-ti-uu - i w konsekwencji - realizuje swój plan, i już imienne od tej chwili stworzonko odchodzi zadowolone. Nazajutrz jednak okazuje się, że Włóczykij ma wyrzuty sumienia i próbuje odnaleźć imiennego już Ti-ti-uu, a kiedy mu się to nie udaje, wymawia życzenie, ujrzawszy księżyc w nowiu (w Dolinie Muminków życzenia spełniają się, gdy Księżyc jest w koniunkcji ze Słońcem). Zupełnie odmienione stworzonko odnajduje się, ciesząc się z ponownego spotkania i wypowiada następujące słowa: 
- To takie emocjonujące! Kiedy nie miałem imienia, rozumiesz, biegałem tylko i najwyżej przeczuwałem to czy owo na temat tego czy owego, a wydarzenia trzepotały wokół mnie; czasem były niebezpieczne, czasem nie, ale nic nie było prawdziwe, rozumiesz? - Włóczykij usiłował coś powiedzieć, ale stworzonko mówiło dalej:

- Teraz jestem osobą, która należy do siebie, i wszystko, co się dzieje, ma znaczenie. Nie dzieje się bowiem „w ogóle”, ale wydarza się mnie, Ti-ti-uu. A Ti-ti-uu patrzy na sprawy tak albo inaczej - jeśli rozumiesz, co mam na myśli.

Włóczykij, nadając bezimiennemu stworzonku imię podczas przypadkowego spotkania, odmienia jego życie, nadając mu sens. Letnie Szkoły są jednymi z tych spotkań, podczas których wielce prawdopodobne wydaje się znalezienie własnego, prywatnego Włóczykija, który (czasem nieświadomie) może sprawić, by rzeczywistość wokół nas „nie trzepotała” i stała się - po prostu - bardziej prawdziwa.

\section{SUMMARY}

\section{The report of the 3oth Summer School for Young Pedagogues}

Katowice-Wisła, september 12-16, 2016

The text constitutes a specific attempt to report the most important and priority events taking place during the unique, because the jubilee, 3oth Summer School for Young Pedagogues under the scientific guidance of professor Maria Dudzikowa and co-organized by the Committee of Pedagogical Sciences of Polish Academy of Sciences and the University of Silesia with the Faculty of Pedagogy and Psychology as a host. Considerations of this year's School oscillated around the theme: "Research traps over education". The aim of the meeting of Young Pedagogues was to exchange views and experiences on methodological ambiguities and complexities and to create convenient, interdisciplinary space of an inspiring, explaining, targeting and building character.

KEY WORDS: Summer School for Young Pedagogues, research traps. 